AperTO - Archivio Istituzionale Open Access dell'Università di Torino

\title{
Distributional dynamics of a specialized subterranean community oppose the classical understanding of the preferred subterranean habitats
}

\section{This is a pre print version of the following article:}

Original Citation:

Availability:

This version is available http://hdl.handle.net/2318/1708840

since 2019-08-07T07:21:54Z

Published version:

DOI:10.1111/ivb.12254

Terms of use:

Open Access

Anyone can freely access the full text of works made available as "Open Access". Works made available under a Creative Commons license can be used according to the terms and conditions of said license. Use of all other works requires consent of the right holder (author or publisher) if not exempted from copyright protection by the applicable law. 


\section{Distributional dynamics of a specialized subterranean community}

\section{2oppose the classical understanding of the preferred subterranean}

\section{3habitats}

4

5Peter Kozel ${ }^{1,2,3, a}$, Tanja Pipan ${ }^{2,3}$, Stefano Mammola ${ }^{4,5}$, David C. Culver ${ }^{6}$ and Tone Novak ${ }^{1}$

$7^{1}$ Department of Biology, Faculty of Natural Sciences and Mathematics, University of 8Maribor, Koroška cesta 160, 2000 Maribor, Slovenia; peter.kozel@um.si; ORCID: 90000-0002-1559-6375, ${ }^{\mathrm{a}}$ Author for correspondence.

$10^{2}$ Karst Research Institute ZRC SAZU, Titov trg 2, 6230 Postojna, Slovenia

$11^{3}$ UNESCO Chair on Karst Education, University of Nova Gorica, Glavni trg 8, 125271Vipava, Slovenia

$13^{4}$ Department of Life Sciences and Systems Biology, University of Torino, Via 14Accademia Albertina 13, 10123 Torino, Italy

$15^{5}$ LIBRe - Laboratory for Integrative Biodiversity Research, Finnish Museum of Natural History, 16University of Helsinki, Helsinki, Finland

$17^{6}$ Department of Environmental Science, American University, 4400 Massachusetts 18Avenue, NW Washington, DC 20016, United States

19

20Abstract. The most specialized organisms to living in the subterranean environment, 21i.e., troglobionts, reside prevalently in the deepest cave zone and shallow subterranean 22habitats and complete their whole life cycles therein. Since troglobionts in most caves 23depend on surface organic matter resources, we hypothesized that they could also select 24the surface-most cave sections, so far the other environmental conditions there are 
25favorable. Over one year, we analyzed the annual distributional dynamics of a 26subterranean community consisting of 17 troglobionts species, in monthly intervals in 27relation with multiple environmental parameters. Cumulative standardized annual 28species richness and diversity clearly indicated the existence of two ecotones within the 29cave: between soil and shallow subterranean habitats, inhabited by soil and shallow 30troglobionts, and between the transition and inner cave zones, where shallow and deep 31troglobionts overlap their spatial niches. The mean standardized annual species richness 32and diversity showed inverse courses, but both contributed to a better insight in the 33dynamics of subterranean fauna. Regression analyses revealed that temperatures 34between $7-10^{\circ} \mathrm{C}$, high ground substrate moisture, large cross-sections size and high 35ground substrate $\mathrm{pH}$ were the most important ecological drivers governing the spatio36temporal dynamics of troglobionts. Overall, this study show general trends in the annual 37distributional dynamics of troglobionts in shallow caves and reveal that the distribution 38patterns of troglobionts within subterranean habitats may be more complex than 39commonly assumed.

40

41Additional key words: cave community, ecological classification, ecotone, pitfall 42trapping, seasonality, spatio-temporal dynamics

43

44Beneath the Earth's surface, various kinds of natural and artificial cavities occur, from 45large cave chambers, to millimeter-sized interspaces between sand grains (Ford \& 46Williams 2007; Palmer 2007; Culver \& Pipan 2009a, b, 2014). Subterranean habitats 47share some common environmental features, which differ distinctively from those found 48on the surface. Subterranean environment is generally characterized by perpetual 
49darkness and reduced variability of abiotic parameters (Culver \& Pipan 2009b; Hüppop 502012). However, seasonal variation in temperature, relative air humidity and some other 51parameters still occurs, which reflect a delayed response to changing weather on the 52surface (Tobin et al. 2013). Surface climate mostly affects the cave sections closest to 53the entrance, while deeper inside the cave, environmental conditions are much more 54stable and the surface effects temporally lag behind (Cigna 2002; Badino 2010; Tobin et 55al. 2013; Šebela \& Turk 2014; Mammola et al. 2015). Another essential difference 56compared to the surface environment is the absence of primary producers in most 57subterranean habitats (Simon et al. 2007; Engel 2012). Consequently, the subterranean 58fauna mostly depends on organic matter input from surface habitats (Gers 1998; 59Poulson \& Lavoie 2000), and is generally poorly diversified (Gibert \& Deharveng 602002). In spite of this, numerous investigations have disclosed a much higher 61biodiversity and a higher degree of endemism among subterranean species than 62predicted previously (e.g., Peck 1998; Culver \& Sket 2000; Elliott 2000; Christman et 63al. 2005; Pipan \& Culver 2007a, b; Zagmajster et al. 2008; Reboleira et al. 2011; 64Deharveng et al. 2012).

65 This diversified subterranean fauna includes temporary and obligate residents of the 66subterranean habitats (Sket 2008; Culver \& Pipan 2009a, 2014; Trajano \& Carvalho 672017). Schiner (1854) and Racoviţă (1907) grounded the ecological classification of the 68subterranean fauna. Despite since then many classifications have been proposed 69(reviewed in Sket 2008; Trajano \& Carvalho 2017), this remains one of the most 70frequently referred classification. Schiner and Racoviţă classified subterranean fauna 71into three ecological groups: (1) Trogloxenes, which do not complete their life cycle in 72subterranean habitats. Accordingly, they should be the most abundant in the entrance 
73cave section. (2) Troglophiles complete their life cycles either in the subterranean or in 74the surface environments, forming populations in both habitats (Sket 2008; Mammola 752018). Some populations do, while others do not complete their life cycle underground. 76(3) Specialized taxa, troglobionts, complete the whole life cycle in the subterranean 77environment (Culver \& Pipan 2009a; Romero 2009; Assmann et al. 2010; Novak et al. 782014). These species are referred to occupy the inner, most stable, cave zone.

79 The spatial distribution of these three ecological groups within subterranean habitats 80is a consequence of variability in environmental parameters and species response to this 81variability mostly on account of seasonal changes in the regional and local climate 82(Novak et al. 2004; Tobin et al. 2013; Lunghi et al. 2017). Classically, it has been 83observed that there is a gradient of subterranean specialization of the biological 84community from the entrance zone toward the deepest sectors (Mammola 2018). 85Accordingly, the community in the vicinity of the surface is usually dominated by 86trogloxenes and troglophiles, whereas troglobionts became progressively more abundant 87at greater depths (Schiner 1854; Racoviţă 1907; Poulson \& White 1969; Culver \& 88Poulson, 1970; Howarth 1983; Tobin et al. 2013). However, recent studies disclosed that 89distributions of taxa in subterranean habitats do not always comply with this general 90pattern (e.g., Novak et al. 2012, Pellegrini \& Ferreira 2016). Surface organisms are 91typically observed even at great depths in caves, for example surface dipterans have 92been observed at $-2140 \mathrm{~m}$ in the Krubera-Voronja Cave, Western Caucasus (Sendra \& 93Reboleira 2012). At the same time, by studying 54 cave communities in Slovenia, 94Novak et al. (2012) showed that troglobionts may consist of two spatially segregated 95groups of species: the shallow and the deep troglobionts, the first being adapted to the 96shallow subterranean habitats and the second to deep subterranean habitats. This, in 
97general, supports the Racoviţă (1907) opinion that many subterranean species normally 98live in fissures and appear in caves by hazard.

99 So far, subterranean habitats have been investigated for their environmental 100conditions in relation to their associated fauna (e.g., Pipan 2005; Culver \& Pipan 2010; 101Tobin et al. 2013; Lunghi et al. 2014, 2017; Prous et al. 2015; Mammola et al. 2015, 1022017; Bento et al. 2016). Distributional dynamics of subterranean fauna, especially 103troglobionts, have rarely been studied. Juberthie (1969) observed daily migrations of the 104troglobiotic beetle Aphaenops cerberus (Coleoptera: Carabidae) between a spacious 105cave and adjacent fissures, driven by changing air movements within the cave; the 106beetles promptly reacted to changes in microclimatic conditions and appeared in the 107cave in a calm only. The same was observed in Leptodirus hochenwartii (Coleoptera: 108Leiodidae) and Anophthalmus hirtus (Coleoptera: Carabidae) (Novak et al. 1980). 109Crouau-Roy et al. (1992) studied the dynamics of different populations of Speonomus 110hydrophilus (Coleoptera: Leiodidae) in a cave and in adjacent network of superficial 111interspaces in-between clastic substrate-the so-called milieu souterrain superficiel 112(MSS)-and observed conspicuous fluctuation in population size and vertical migration 113over the year. This was triggered by seasonal variation of environmental parameters, 114 especially temperature and relative air humidity. Significant vertical migration between 115MSS and caves owing to seasonal fluctuations in temperature has also been recorded in 116other subterranean species (Chapman 1985; Polak 2012; Mammola et al. 2016). Beside 117variation in climatic conditions, trophic availability was found to be an important factor 118affecting the spatial distribution of several spider species inhabiting caves (e.g., Novak 119et al. 2010; Manenti et al. 2015; Mammola \& Isaia 2014, 2016; Lunghi 2018). 120Furthermore, the spatial distribution of particular subterranean species is also affected 
121by the structural complexity of cave walls (e.g., Bourne 1976, 1977; Mammola \& Isaia 1222014, 2016).

123 While evident patterns in distributions of single troglobiotic species in caves are 124reported, great gaps remains in knowledge about distributional dynamics of the whole 125troglobiotic community. Despite extensive research in recent decades, subterranean 126organisms remain among the least understood groups in the world (Soares \& Niemiller 1272013). Under this perspective, the study of distributional dynamics of troglobionts may 128help us to achieve a better understanding of their preferred subterranean habitats and 129microhabitats. In the present research, we studied the annual dynamics of troglobiont 130community in a cave in Slovenia, with the aim of exploring whether troglobionts could 131occur in the surface-most cave sections, rather than exclusively in the deepest cave 132sectors, and to find out which environmental parameters would influence such 133distribution. We hypothesized that: (1) Variation in the environmental conditions along 134the cave length primarily drive spatial dynamics of troglobionts. (2) Seasonal variation 135in the environmental parameters determine parallel seasonal changes in troglobiotic 136community along the cave, eventually permitting the colonization of surface-most 137sector during favorable periods.

138

\section{Methods}

\section{Study site}

143 We carried out the study in the cave Zguba jama (Cadastre number 6290; E 14414'12’49.57’, N 4547’47.50”; 561 m a.s.l.; Cave Register Karst Research Institute 
145ZRC SAZU and Speleological Association of Slovenia) near Postojna, Slovenia (Fig. 1461). This relatively small, horizontal cave is $122 \mathrm{~m}$ long, with a $1.5 \mathrm{~m}$ wide by $1 \mathrm{~m}$ high 147entrance. This study site was chosen owing to its simple morphology, linear shape and 148nearly constant cross-section $(2 \times 2 \mathrm{~m}$ average cross-section, with a few largest sites 149where the ceiling reaches a 5-m-height), allowing us to sample the species and 150measuring the considered environmental parameters in a more standardized way. The 151cave is in close vicinity of the Postojna cave (Šebela 1994), one of the world's hotspots 152of subterranean fauna (Culver \& Sket 2000; Zagmajster et al. 2008; Sket 2012; Culver 153\& Pipan 2013). It hosts a rich and diverse community, consisting of more than 100 154species of which at least 17 can be classified as troglobionts (Kozel et al. 2017).

155

\section{Sampling design}

158 To study the distributional dynamics of troglobionts, we defined 31 , on average $4 \mathrm{~m}$ 159long, sampling sections in the cave (Fig. 2). The cave was surveyed twice a month 160within about 48 hours over one year, from March 2012 to February 2013. The 161environmental parameters, which may vary considerably in subterranean microhabitats 162across one year (Cigna 2002, Badino 2010), were measured monthly at the first monthly 163survey in each sampling site. We took monthly records of the air temperature (Tair) and 164relative air humidity (RH) at the ground and below the ceiling using a handheld 165aspiration psychrometer (Ahorn FN A846, Germany) fastened on a $2 \mathrm{~m}$ long stick to 166diminish disturbance by the researcher. A sonde thermometer (Checktemp 1, Hanna, 167 Germany) was used to measure the ground temperature (Tgr) at a depth of $2 \mathrm{~cm}$. The 168substrate samples (ca. $100 \mathrm{~g}$ ) were collected at ca. $0.25 \mathrm{~m}^{2}$ area around the pitfall traps. 
169The substrate moisture content (MC) was determined after drying samples at $105^{\circ} \mathrm{C}$ in 170the laboratory heating oven until reaching the stable weight. Conversely, more stable 171parameters over the year were measured only once, during the first survey. The $\mathrm{pH}$ of 172the ground substrate (pHgr) was measured with a pH-meter (Hanna Instruments HI221 173Calibration Check, Microprocessor $\mathrm{pH}$ Meter, Woonsocket, RI, USA), and the carbonate 174content (CC) in the substrate by means of Scheibler's calcimetry. Organic material 175 content $(\mathrm{OM})$ was determined after the ignition of dry substrate samples at $650^{\circ} \mathrm{C}$ in a 176muffle furnace until reaching a constant weight. The distance from the entrance (DisE; 177polygonal distance) and from the surface (DisS; vertical distance) of the center of the 178sampling sections were calculated upon the ground cave plan and terrain profile above 179the cave. The passage cross-section size (Size) and the sampling section area (Area), 180i.e., wall and ceiling surface area, were, simplified, considered as being an open 181cylinder. The average mean height and width of each sampling section were used to 182calculate the radius of the circle. Chimneys and concavities were additionally taken into 183account.

184 The fauna was recorded by visual inspection and by pitfall trapping. We applied 185simultaneously two sampling methods, since it is documented that complementary 186sampling approaches maximize the detection and completeness of diversity of cave187dwelling arthropods (Kozel et al. 2017; Wynne et al. 2018, 2019).

188 For visual inspection, we devoted 0.5 minute $/ \mathrm{m}^{2} /$ observer. Only individuals that we 189could not identify to the species level in the cave were taken in the laboratory for 190identification. In order to investigate simultaneously the fauna occurring on the ground 191and on walls (Kozel et al. 2017), we used two parallel sets of pitfall traps: the ground set 192and the upper set-close below the ceiling-along the cave (Fig. 2). Pitfall traps were 
193baited with decomposing beef meat and apple juice with a lacing of cherry and 194maraschino essence, and a few drops of detergent to reduce the surface tension. 195Sampling of fauna was carried out within two visits a month. At the first visit, we 196visually inspected the cave for the fauna and set the traps. At the second visit, within 197about 48 hours, we picked up the traps and took them into laboratory for identification. 198The voucher specimens preserved in $70 \%$ ethanol are deposited at the Faculty of 199Natural Sciences and Mathematics, University of Maribor. For details on the traps see 200Kozel et al. (2017). Counts deriving from visual inspection and pitfall trapping were 201merged in the analysis (Wynne et al. 2019).

202

\section{Data analysis}

204

205 To graphically visualize the overall environmental conditions along the cave, 206microclimatic and physical parameters were mapped using ArcGIS Desktop 10.3.1 (Esri 2072015). We created a vector layer of the cave, projecting it "on the fly" over the original 208raster scheme of the cave. The point station data were interpolated by Inverse Distance 209Weighted (IDW) tool, using a power of 2 as exponent of distance and a cell size of 2 for 210all resulting grid maps.

211 The sampling sections on each sampling date were used as basic sample units. Mean 212values of Tair and RH from the ground and below-ceiling measurements, and the 213distances from the entrance and from the surface were used in the statistical analyses. 214Data on fauna recorded by visual inspection and pitfall trapping were pooled for the 215analyses. 
216 In order to investigate the annual dynamics of troglobionts with respect to the 217environmental parameters, we applied generalized linear mixed models (GLMMs). The 218mixed procedure allowed us to deal with replicated prospections of the sampling 219section, by specifying the sampling section as a random factor. We modeled abundance 220and presence-absence data of troglobionts separately. In the abundance approach, we 221used counts of individuals deriving from pitfall and visual inspections as the response 222variable. To adjust the abundance for the different sizes of the sampling sections, we 223included the sampling section area (Area) as an offset in the model.

224 Given the low richness of species per sampling section (ranging from 0 to 4 225species, with most values being either 0 or 1 ), we expressed richness as presence or 226absence of troglobionts within the sampling plot (i.e., Bernoulli distribution $0-1$ ). This 227 model allowed us to uncover fundamental conditions governing the presence of 228troglobionts in the cave, thus complementing the abundance approach.

229 The following independent variables were addressed as potential predictors of the 230dependent variables: distance from the entrance (DisE), distance from the surface 231(DisS), Season (Sea; consisting of four levels: "Spring", "Summer", "Autumn", 232“Winter"), ground temperature (Tgr), air temperature (Tair), relative air humidity (RH), 233substrate moisture content (MC), ground substrate $\mathrm{pH}(\mathrm{pHgr})$, organic material content 234(OM), carbonate content (CC), and passage cross-section size (Size). All variables but 235season were continuous.

236 Prior to model fitting, a systematic data exploration was carried out following the 237protocol proposed by Zuur et al. (2010). Including outliers or highly correlated variables 238increase type I and II statistical errors and may potentially result in incorrect ecological 239conclusions (Zuur et al. 2009, 2010). Accordingly, Cleveland dotplots were used to 
240assess the presence of outliers in response and explanatory variables and multi241collinearity among continuous variables was tested using Pearson correlation 242coefficients and variance inflation factors (VIF), setting $r \geq \pm 0.7$ and VIF $>3$ as cut-off 243values (Zuur et al. 2013). Collinearity between continuous variables and the categorical 244variable Season was assessed graphically through boxplots. Possible non-linear effects 245of the continuous variables included in the models were investigated with generalised 246additive models (GAM), using the gam R package (Hastie 2016). Coplots were further 247constructed to check for potential interactions between Season and the continuous 248covariates.

249 The abundance of troglobionts was modeled choosing a negative binomial 250distribution family, the distribution applied for over-dispersed count data (Zuur et al. 2512009). The presence-absence of troglobionts was modeled through Binomial GLMM 252using a complementary log-log link (clog-log), owing to unbalanced zeros (absences) 253and ones (presences) in the dataset (Zuur et al. 2009). All models were fitted through the 254glmer command from the lme4 R package (Bates et al. 2016).

255 After fitting the initial models, including all non-collinear covariates of interest, we 256conducted model selection (Johnson \& Omland 2004). A backward elimination 257procedure was chosen, whereby variables were progressively deleted according to AICc 258values (Burnham \& Anderson, 2002). AICc values were calculated in the MuMIn R 259package (Bartón 2018). The backward elimination procedure was reiterated manually 260until a minimum adequate model consisting exclusively of statistically significant 261variables was obtained. Model validation was carried out on the final models in 262accordance with Zuur et al. (2009, 2013). Factor significance was checked via 263likelihood ratio test. 
264 Species richness and diversity of troglobionts for each sampling section and each 265month were calculated. Species diversity was calculated through the Shannon-Weaver 266index (H') for each sampling section and each month using the vegan $\mathrm{R}$ package 267(Oksanen et al. 2016). Given the unequal sampling section sizes, both variables were 268standardized by dividing the corresponding value by the sampling section area. 269Spearman rank correlation coefficient (rs) between species richness and diversity was 270calculated.

271 Variation in species richness and diversity along the cave was evaluated by fitting a 272GAM into the data. All statistical analyses were carried out in the $\mathrm{R}$ environment ( $\mathrm{R}$ 273Development Core Team, 2018).

274

275Results

276

277Environmental parameters

278

279 The annual characteristics of the environmental parameters along the cave are 280presented in Fig. 3. In terms of variation of climatic conditions, we distinguished three 281cave zones: the entrance (sampling sections 1-8), the transition (sampling sections 928213) and the inner zone (sampling sections 14-31). The entrance zone showed the 283greatest variation in annual temperature (Tair, Tgr) and humidity (RH), which was 284considerably influenced by the external climatic conditions (Fig. 3A-C). In this 285illuminated zone, air temperature varied annually from -3.6 to $15.1^{\circ} \mathrm{C}$, ground 286temperature from -0.4 to $14.4^{\circ} \mathrm{C}$ and relative humidity from 80.1 to $100 \%$. The 287transition zone was characterized by intermediate variations of these parameters with 
288respect to the entrance and the inner zones, including twilight in the beginning and total 289darkness in the inner part of the transition zone. Air temperature varied from 6.6 to $2908.5^{\circ} \mathrm{C}$, ground temperature from 7.2 to $8.5^{\circ} \mathrm{C}$ and relative humidity was close to 291saturation (variation between $98.5^{\circ} \mathrm{C}$ and $100 \%$ ). The inner, completely dark zone was 292relatively stable, with only limited variations in air $\left(7.9-9.1^{\circ} \mathrm{C}\right)$ and ground temperature 293 $\left(8.0-9.1^{\circ} \mathrm{C}\right)$. Relative humidity remained constant at saturation. Annual mean air and 294ground temperature and relative humidity gradually increased, and variation in these 295parameters were progressively attenuated, along with increasing distance from the 296entrance.

297 The substrate moisture content (Fig. 3D) varied from 7.92 to $50.26 \%$ and carbonate 298content (Fig. 3E) from 0 to $53.35 \%$. Both parameters showed no pattern with respect to 299distance from the entrance. The organic material varied from 2.36 to $59.79 \%$ along the 300cave. The greatest share (Fig. 3F) was recorded in the entrance zone, and the lowest in 301the middle of the cave. Disregarding the sampling section 1, with a large amount of 302organic matter in the floor substrate, relatively low variation of organic material among 303other sampling sections was found. The $\mathrm{pH}$ (Fig. 3G) varied from 7.82 to 8.38 and was 304relatively stable along the cave.

305

306Annual and monthly species richness and diversity of troglobionts 307

308 Altogether, we recorded 1,546 individuals belonging to the following 17 troglobiont 309species: Absolonia gigantea, Androniscus sp., Arrhopalites postumicus, 310Bathyscimorphus byssinus, Bathysciotes khevenhuelleri, Brachydesmus subterraneus, 311cf. Linopodes sp., Oncopodura cavernarum, Leptodirus hochenwartii, Neelus sp., 
312Neobisium spelaeum, Onychiuroides postumicus, Plusiocampa sp., Stalita taenaria, 313Titanethes albus, Troglopedetes pallidus, Zospeum spelaeum spelaeum.

314 Cumulative standardized annual species richness and diversity of troglobionts 315showed a very high correlation $\left(\mathrm{r}_{\mathrm{s}}=0.87, \mathrm{p}<0.001\right)$. Both were lowest in the entrance and 316transition zones and greatest in the inner zone. However, two peaks appeared in the 317sampling section 1 in the contact zone of surface and subterranean environments, and in 318the sampling section 15 in the contact of the transition zone and the inner cave zone 319(Fig. 5A).

320 Mean standardized annual species richness and diversity of troglobionts showed 321moderate correlation $\left(\mathrm{r}_{\mathrm{s}}=0.44, \mathrm{p}<0.013\right)$. Comparing cumulative and standardized 322curves, they showed inverse courses. Both curves showed the lowest values at the very 323entrance, in the contact between the transition and inner zones, and at the very end of 324the cave, with two inconspicuous peaks in the entrance and inner zones (Fig. 5B). High 325correlation $\left(\mathrm{r}_{\mathrm{s}}=0.76, \mathrm{p}=0.004\right)$ was found between monthly species richness and 326diversity of troglobionts. There were three distinctive peaks in species richness (May327June 2012, August-September 2012, December 2012) and diversity (June 2012, 328September 2012, January 2013) (Fig. 6). The lowest species richness was recorded in 329July 2012 and the lowest diversity in March 2012. Both showed a trend of slight 330increasing from March 2012 until January 2013.

\section{Environmental parameters influencing the abundance of troglobionts}

334 Data exploration revealed the presence of one outlying value in the dependent 335variable (abundance), which was removed from the dataset. The variables organic 
336material content, carbonate content and relative air humidity contained outliers that 337could not be stabilized even after the transformation. Since excluding these numerous 338outliers would significantly reduce the dimension of the dataset, and since data 339exploration revealed that these three variables were not strongly correlated with our 340dependent variable, we removed these three variables from the analysis. The variable 341passage cross-section size was log-transformed to homogenize its distribution. Air 342temperature, being collinear with ground substrate temperature $(r>0.7)$, and distance 343from the entrance, being collinear with distance from the surface $(r<0.7)$, were dropped 344from the analysis. Coplots revealed a possible interaction between distance from the 345entrance and the seasons. Finally, a non-linear effect of the ground temperature was 346detected during data exploration, and accounted for by introducing squared ground 347temperature as a term in the regression structure. Accordingly, we included, as variables 348in the initial model, the interaction between distance from the entrance and Season, log349transformed passage cross-section size, substrate moisture content, ground substrate 350temperature and its square, and ground substrate $\mathrm{pH}$.

351 According to model selection based on AICc values (Table 1), the most appropriate 352model that explained the abundance of troglobionts had the following structure:

$$
\mathrm{y} \sim \text { DisE*Season }+ \text { Tgr }+ \text { Tgr }^{2}+\mathrm{MC}+\text { offset(Area) }+1 \mid \text { Sampling site. }
$$

356 The combined effect of these variables on the abundance of troglobionts is illustrated 357in Fig. 7. The abundance of troglobionts was significantly greater near the cave entrance 358and decreased with increasing distance from the entrance in Spring 359(Season_Spring*DisE Estimated $\beta \pm \mathrm{SE}:-0.0163 \pm 0.0052, \quad \mathrm{p}=0.002$ ) and Summer 
360(Season_Summer*DisE Estimated $\beta \pm \mathrm{SE}:-0.0183 \pm 0.0047, \quad \mathrm{p}<0.001$ ) relative to 361Autumn. Instead, the abundance of troglobionts was lower and not significantly 362different in Winter (Season_Winter*DisE Estimated $\beta \pm S E$ : $-0.0082 \pm 0.0052, p=0.120$ ). 363The abundance of troglobionts also increased with increasing ground substrate 364temperature (Tgr Estimated $\beta \pm \mathrm{SE}: 1.1850 \pm 0.3840, \mathrm{p}=0.002$ ) and decreased with 365squared ground substrate temperature $\left(\operatorname{Tgr}^{2}\right.$ Estimated $\beta \pm \mathrm{SE}:-0.0839 \pm 0.0279$, $366 \mathrm{p}=0.003)$. The combination of the latter two effects resulted in a parabolic trend, with 367the greatest abundance of troglobionts at temperatures comprised between 7 and $10^{\circ} \mathrm{C}$. 368Moreover, we found an increase in the abundance of troglobionts with increasing values 369of substrate moisture content (MC Estimated $\beta \pm \mathrm{SE}: 0.0307 \pm 0.0114, \mathrm{p}=0.007$ ).

370

371Environmental parameters influencing the presence of troglobionts

373 During data exploration, no outliers were detected. The same procedure as described 374in detail in the previous analysis, and the same variables, except $\operatorname{Tgr}^{2}$, were included in 375the initial model. According to model selection (Table 1), based on AICc values, the 376most appropriate model explaining the probability of the presence of troglobionts, had 377the following structure:

378 $\mathrm{y} \sim$ DisE*Season+logSize+pHgr+1|Sampling site.

381 The combined effect of these variables on the probability of the presence of 382troglobionts is illustrated in Fig. 8. The probability of the presence of troglobionts 383decreased significantly with increasing distance from the entrance in Spring 
384(Season_Spring*DisE Estimated $\beta \pm \mathrm{SE}:-0.0156 \pm 0.0057, \mathrm{p}=0.006$ ) and Summer 385(Season_Summer*DisE Estimated $\beta \pm \mathrm{SE}:-0.0146 \pm 0.0056, \mathrm{p}=0.010$ ) with respect to 386Autumn. On the other hand, the presence of troglobionts was lower in Winter, but not 387significantly different (Season_Winter*DisE Estimated $\beta \pm$ SE: $\quad-0.0057 \pm 0.0055$, $388 \mathrm{p}=0.299$ ). We also found an increase in the probability of the presence of troglobionts 389with increasing log-transformed passage cross-section size $(\log$ Size Estimated $\beta \pm \mathrm{SE}$ : $3900.5380 \pm 0.2178, \quad \mathrm{p}=0.013)$ and ground substrate $\mathrm{pH}$ (pHgr Estimated $\beta \pm \mathrm{SE}$ : $3911.7096 \pm 0.8268, \mathrm{p}=0.039)$.

392

\section{Discussion}

395 Subterranean habitats are suitable for studying species interactions, ecological 396niches, and temporal and spatial patterns in terrestrial subterranean communities. 397However, subterranean communities as a whole are only rarely considered in relation 398with environmental conditions (e.g., Di Russo et al. 1997; Pipan et al. 2011; Sendra \& 399Reboleira 2012; Tobin et al. 2013; Bento et al. 2016; Mammola et al. 2017; Mammola 400\& Isaia 2018). Consequently, community responses to environmental conditions are still 401poorly understood.

402 High correlations between cumulative standardized species richness and diversity of 403troglobionts on annual and monthly scales suggest that either of these measures provide 404equivalent insight into the dynamics of the troglobiotic community. In the entrance cave 405zone, the gradual decrease of both species richness and Shannon-Weaver diversity of 406troglobionts, with the highest values at the very entrance, suggests that there is an 407ecotone between soil and shallow karst habitats, where soil and shallow subterranean 
408troglobionts temporarily occur. A similar situation also occurs at the boundary between 409the transition and the inner cave zones. This suggests that there is another ecotone 410where shallow troglobionts, which regularly inhabit shallow subterranean habitats, meet 411deep troglobionts, regularly occurring in the inner cave zone. Thus, in the entrance cave 412zone, trogloxenes, troglophiles and, temporary, shallow troglobionts regularly occur, 413while in the inner cave zone deep troglobionts, and, temporary, troglophiles and 414trogloxenes occur. Culver and Pipan (2014) argued that deep soil habitats host a range 415of troglomorphic species, which have been largely neglected in current speleobiological 416studies. Until very recently, troglobionts have been discussed as a unique, convergent 417ecological and morphological group. However, divergence governed by competition and 418other factors also takes place in the subterranean habitat (Pipan \& Culver 2012). The 419result of this study support previously published evidence (Novak et al. 2012, 2014), 420suggesting that there is a clear separation of troglobiotic species inhabiting shallow and 421deep subterranean habitats. The entrance cave zone may thus be seen as an ecotone 422between the surface and subterranean environments (Prous et al. 2004, 2015), the 423boundaries of which are poorly defined (Mammola et al. 2017) and which is 424characterized by relatively high fluctuation of meteorological conditions (Pipan et al. 4252011). Compared to inner cave sectors, this ecotone has received only limited study (but 426see, e.g., Prous et al. 2004, 2015; Hobbs 2012; Culver \& Pipan 2014; Yao et al. 2016; 427Lunghi et al. 2017). Consequently, it has remained uncovered whether deep edaphic and 428cryptic ground species with troglomorphic appearance should be distinguished from 429shallow troglobionts or not. However, further research on the life cycles, physiology and 430population structure of troglobionts inhabiting these two zones are required. The mean 431standardized species richness and diversity of troglobionts on annual scale, on the other 
432hand, reflect other community characteristics, referring the environmental conditions 433within the cave. Over the year, most favorable environmental conditions for shallow 434troglobionts appeared at the end of the entrance zone, while such conditions for deep 435troglobionts were in the middle of the inner zone. Consequently, both approaches 436contribute to better understanding the dynamics of troglobiont communities.

437 Seasonality manifests in species distributions through altering the presence and the 438abundance of certain species in a given place at a stated time (Murray et al. 2013; 439Lunghi et al. 2017). Seasonality affects many biotic functions, such as growth, feeding, 440and reproduction (Araújo et al. 2010; Hjernquist et al. 2012). In our study, troglobionts 441showed a conspicuous spatial distribution pattern that varied seasonally. In spring and 442summer, greater abundance and higher probability of presence were found near the 443entrance; these declined with increasing distance from the entrance. The same 444distributional pattern also applies in the case of distance from the surface, being 445collinear with the distance from the entrance. Although in Zguba jama, air and ground 446temperature and humidity, passage cross-section size and $\mathrm{pH}$ significantly influenced 447the troglobionts, this may not be the general rule in other cave types, e.g., in ice caves 448(cf. Raschmanová et al. 2018). A similar spatial pattern has been observed in the 449troglophile beetle Sphodropsis ghilianii (Mammola et al. 2015). Our results show that 450greater abundance of troglobionts occurs at ground temperatures between 7 and $10{ }^{\circ} \mathrm{C}$ 451and high ground substrate moisture, which may represent optimal microclimatic 452conditions. The optimal temperatures well fit the average annual temperature in 453Postojna (Postojna Meteorological Station). Such conditions were present near the 454entrance in spring and summer, which may in turn explain the greater abundance of 455troglobionts in these seasons. Our findings are in accordance with the generally 
456accepted understanding that troglobionts are adapted to narrow ranges of temperature 457and humidity (Barr \& Kuehnelt 1971; Howarth 1980). They are more susceptible to 458desiccation, owing to their thinner exoskeleton, as compared to their surface 459counterparts (Howarth 1980). Furthermore, the higher availability of prey and organic 460matter deposits in the vicinity of the entrance (Tobin et al. 2013; Mammola \& Isaia 4612016) likely constitute additional essential factors determining the highest abundance of 462troglobionts in the entrance zone in spring and summer. In autumn and winter, lower 463abundance and probability of the presence of troglobionts near the entrance refer to 464unfavorable conditions. Most likely, these triggered the migration of troglobionts from 465the cave into the adjacent fissure network and partly towards climatically more stable 466inner cave zone. Prompt migrations, as a response to changes in microclimatic 467conditions, have been reported in different subterranean beetles (e.g., Aphaenops 468cerberus - Juberthie 1969; Drimeotus - Racoviţă 1983; Speonomus hydrophilus 469Crouau-Roy et al. 1992; Parapropus sericeus and Prospelaeobates brelihi - Polak 4702012; Sphodropsis ghilianii - Mammola et al. 2015). Troglobionts found near the 471entrance in winter are presumably adapted to more severe and variable environmental 472conditions. They probably possess moderate freezing tolerance, being able to withstand 473short exposure to sub-zero temperatures (e.g., Lencioni et al. 2010; Novak et al. 2014), a 474general feature of shallow (Novak et al. 2014) and some deep troglobionts 475(Raschmanová et al. 2018). In autumn and winter, slightly greater species richness and 476diversity were recorded. This might suggest that the most suitable microclimatic 477conditions for troglobionts occurred in these periods. On the other hand, low abundance, 478along with higher species richness resulted in greater diversity of troglobionts in these 479seasons. 

481of troglobionts probably because these cave sections provide more microhabitat types 482and a calmer atmosphere. This apparently contradicts findings in some troglobiotic 483beetles, which show strong preference for narrow spaces but are highly sensitive to air 484currents in large passages (e.g., Aphaenops - Juberthie 1969; Juberthie \& Bouillon 4851983; Speonomus - Delay 1978; Leptodirus, Anophthalmus - Kuštor \& Novak 1980a, 486b). In relatively small caves, such as Zguba jama, the Bernoulli principle seems to be the 487most important agent affecting the air current velocity leaving no calm portions in 488narrow passages, but allowing some calm microhabitats in more spacious cave parts.

489 Ground substrate $\mathrm{pH}$ was found to be another factor importantly affecting the 490presence of troglobionts; the higher the substrate $\mathrm{pH}$, the greater the probability of their 491presence. A study on bacterial community in a cave indicated that higher substrate $\mathrm{pH}$ 492proposed a greater diversity of bacteria (Yun et al. 2016). As already reported by Vandel 493(1965), obligate argilivory, i.e., feeding on clay, is common in troglobiotic taxa, such as 494beetles of the family Leiodidae (Moldovan 2012) and the harvestman Ischyropsalis 495hadzii (own unpublished data). Leahy and Colwell (1990) found that a decrease in $\mathrm{pH}$ 496from 8.5 to 7.4 significantly increased the decomposition rates of organic matter by 497microbes, which might consequently result in lower food availability for troglobionts. 4980rganic matter did not affect the distribution of troglobionts, since, except the humus 499accumulation at the entrance, there were no further accumulations of organic matter, and 500 its contents in the floor substrate was relatively low and stable along the cave.

501 It is worth noting that abundance and richness data deriving from baited pitfall502trapping must be carefully considered since these results might differ in comparison to 503other methods (Poulson \& Culver, 1968; Juberthie, 1969; Kuštor \& Novak, 1980a, b; 
504Weinstein \& Slaney, 1995; Culver \& Pipan, 2009; Kozel et al. 2017; Wynne et al., 5052019). However, in previous studies (Novak et al. 2012; Kozel et al. 2017) we showed 506that a monthly two-day setting of the traps being 3-4 m distant from each other provides 507enough data for many statistical analyses, along with any detectable influence on the 508depletion of the fauna.

509 Our finding that most troglobiotic species preferred the inner, climatically the most 510stable, cave zone, is in accordance with general trends that species richness and 511diversity of troglobionts are typically greatest deeper inside caves (Schiner 1854; 512Racoviţă 1907; Poulson \& White 1969; Howarth 1983; Tobin et al. 2013). However, 513this is in contrast to Novak et al. (2012), who found that most troglobionts are 514distributed within the upper $10 \mathrm{~m}$ of subsurface strata. This difference in the findings 515 might be the consequence of either comparing only one (our study) vs. a large number 516of caves (Novak et al. 2012) or due to different sampling efforts (monthly vs. seasonal 517sampling).

518 In conclusion, in speleological terms, Zguba jama is a relatively short cave, shallow 519beneath the surface. The mean annual air temperature roughly corresponds to the mean 520annual air temperature outside. The other environmental characteristics, such as relative 521humidity, substrate moisture content, organic matter content and $\mathrm{pH}$, are typical of caves 522in the region (own unpublished data). Although partitioning caves into the entrance, 523intermediate and inner zones is conceptually clear, in caves some practical guidelines 524are needed. In moderate climates, the entrance cave zone is illuminated, the air and 525ground temperatures may fall below $0^{\circ} \mathrm{C}$ and the relative humidity is nearly all the time 526below $100 \%$. The intermediate zone is a twilight or completely dark zone, where the 527temperatures never fall below $0^{\circ} \mathrm{C}$, while the relative humidity may be lower than 100 
$528 \%$ at least in one season. The inner zone is completely dark and thermally (temperature 529variation usually less than $1{ }^{\circ} \mathrm{C}$; Cigna 2002) and humidity stable (saturated or 530subsaturated). In most caves the three zones can only be identified after checking the 531illumination, and measuring annual variation of air and ground temperature and relative 532humidity at least once each season. Two ecotones: the entrance and the inner one can be 533distinguished in the cave, the first one sharing the edaphic and shallow troglobiont 534faunas, and the second one the shallow troglobiont and deep troglobiont faunas. 535Cumulative and standardized data on species richness and diversity reveal different 536population properties; consequently, both approaches should be applied in future studies 537to get a better insight in the dynamics of subterranean fauna. In this study we identified 538the most important environmental parameters affecting spatio-temporal dynamics of 539troglobionts in the cave. Hosting a relatively rich fauna (Kozel et al. 2017) and being 540easily modeled due to its horizontal development and simple shape, this cave well 541serves as an amenable model to study the annual distributional dynamics of troglobionts 542in shallow caves.

\section{3}

544Acknowledgements. We are indebted to Marco Isaia for helpful discussion and 545 comments on the initial version of the manuscript. We thank Giulio Gardini and Marko 546Lukić for determination of Pseudoscorpiones and Collembola, respectively, to Petra 547Gostinčar for preparing the map of the study site, and Magdalena Năpăruş-Aljančič for 548help with GIS. Peter Kozel also thanks the Slovenian Research Agency, Program for 549young researchers, for the grant. Enrico Lunghi and an anonymous referee provided 550useful comments and suggestions during the review process. 


\section{References}

553Araújo CS, Candido DM, Araújo HFP, Dias SC, \& Vasconcellos A 2010. Seasonal 554 variations in scorpion activities (Arachnida: Scorpiones) in an area of Caatinga 555 vegetation in northeastern Brazil. Zoologia 27: 372-376.

556Assmann T, Casale A, Drees C, Habel JC, Matern A, \& Schuldt A 2010. Review: The 557 dark side of relict species biology: Cave animals as ancient lineages. In: Relict 558 Species: Phylogeography and Conservation Biology. Habel JC \& Assmann T, eds., 559 pp. 91-102. Springer-Verlag, Berlin.

560Badino G 2010. Underground meteorology. What's the weather underground? Acta 561 Carsol 39: 427-448.

562Barr TC, \& Kuehne RA (1971). Ecological studies in the Mammoth Cave system of

563 Kentucky. II. The ecosystem. Annal. Spéléol. 26: 47-96.

564Bartón K 2018. MuMIn: Multi-Model Inference. $\mathrm{R}$ package version 1.42.1. 565 https://CRAN.R-project.org/package=MuMIn

566Bates D, Maechler M, Bolker B, Walker S, Bojesen Christensen RH, Singmann H, Dai

567 B, Grothendieck G, \& Green P 2016. Ime4: Linear Mixed-Effects Models using 568 'Eigen' and S4. R package version 1.1-19. https://CRAN.R-project.org/package=lme4 569Bento DdeM, Ferreira RL, Prous X, Souza-Silva M, Bellini BC, \& Vasconcellos A 570 2016. Seasonal variations in cave invertebrate communities in the semiarid Caatinga,

571 Brazil. J. Cave Karst Stud. 78: 61-71.

572Bourne JD 1976. Notes préliminaires sur la distribution spatiale du Meta menardi,

573 Triphosa dubitata, Triphosa sabaudiata, Nelima aurantiaca et Culex pipiens au sain

574 d'un écosystéme cavernicole (Grotte de Scierce: Mte. Savoie). Int. J. Speleol. 8: $575 \quad 253-267$. 
576Bourne JD 1977. Mise en evidence de groupements temporaires de la faune pariétale 577 dans un tunnel artificiel en fonction de l'humidité et des mouvements d'air. Rev. 578 Suisse Zool. 84: 527-539.

579Burnham KP, \& Anderson DR 2002. Model Selection and Multimodel Inference: a 580 practical information-theoretic approach. Springer, New York, 488 pp.

581Chapman PRJ 1985. Are the cavernicoles found in Hawaiian lava tubes just visiting? 582 Proc. Univ. Bristol. Spel. Soc. 17: 175-182.

583Christiansen KA 1962. Proposition pour la classification des animaux cavernicoles. 584 Spelunca 2: 76-78.

585Christman MC, Culver DC, Madden M, \& White D 2005. Patterns of endemism of the 586 eastern North American cave fauna. J. Biogeogr. 32: 1441-1452.

587Cigna AA 2002. Modern trend in cave monitoring. Acta Carsol. 31: 35-54.

588Crouau-Roy B, Crouau Y, \& Ferre C 1992. Dynamic and temporal structure of the 589 troglobitic beetle Speonomus hydrophilus (Coleoptera: Bathysciinae). Ecography 15: $590 \quad 12-18$.

591Culver DC, \& Sket B 2000. Hotspots of subterranean biodiversity in caves and wells. J. 592 Cave Karst Stud. 62: 11-17.

593Culver DC 1976. The evolution of aquatic cave communities. Am. Nat. 110: 949-957. 594Culver DC, \& Pipan T 2009a. The biology of caves and other subterranean habitats. 595 Oxford University Press, New York, 272 pp.

596Culver DC, \& Pipan T 2009b. Superficial subterranean habitats - gateway to the 597 subterranean realm? Cave Karst Sci. 35: 5-12.

598Culver DC, \& Pipan T 2010. Climate, abiotic factors, and the evolution of subterranean 599 life. Acta Carsol. 39: 577-586. 
600Culver DC, \& Pipan T 2013. Subterranean Ecosystems. In: Encyclopedia of 601 Biodiversity, 2nd ed. Levin SA, ed., pp 49-62. Academic Press, Massachusetts.

602Culver DC, \& Pipan T 2014. Shallow subterranean habitats: ecology, evolution, and 603 conservation. Oxford University Press, Oxford, 258 pp.

604Culver DC, \& Poulson T 1970. Community boundaries: faunal diversity around a cave 605 entrance. Ann Spéléol 25: 853-860.

606Deharveng L, Gibert J, \& Culver DC 2012. Diversity Patterns in Europe. In: 607 Encyclopedia of caves, 2nd ed. White WB \& Culver DC, eds., pp. 219-228. 608 Academic Press. Amsterdam.

609Delay B 1978. Milieu souterrain et la écophysiologie de la reproduction et du 610 développement des Coléoptères Bathysciinae. Mém. Biospéol. 5: 1-349.

611Di Russo C, Carchini G, Rampini M, Lucarelli M, \& Sbordoni V 1997. Long term 612 stability of a terrestrial cave community. Int. J. Speleol. 26: 75-88.

613Elliott WR (2000) Conservation of the North American cave and karst biota. In: 614 Ecosystems of the World, 30. Subterranean Ecosystems. Wilkens H, Culver DC \& 615 Humphreys WF, eds., pp 665-689. Elsevier, Amsterdam.

616Engel AS 2012. Chemoautotrophy. In: Encyclopedia of caves, 2nd ed. White WB \& 617 Culver DC, eds, pp 125-134. Academic Press, Amsterdam.

618Esri 2015. ArcGIS Desktop: release 10.3.1. CA: Environmental Systems Research 619 Institute.

620Ford D, \& Williams P 2007. Karst hydrogeology and geomorphology. John Wiley \& 621 Sons, Chichester, $576 \mathrm{pp}$.

622Gers C 1998. Diversity of energy fluxes and interactions between arthropod 623 communities: from Soil to Cave. Acta Oecol. 19: 205-213. 
624Gibert J, \& Deharveng L 2002. Subterranean ecosystems: a truncated functional 625 biodiversity. BioScience 52: 473-481.

626Hastie T 2016. Gam: Generalized Additive Models. R package version 1.16. 627 http://CRAN.R-project.org/package=gam

628Hjernquist MB, Söderman F, Jönsson KI, Herczeg G, Laurila A, \& Merilä J 2012.

629 Seasonality determines patterns of growth and age structure over a geographic 630 gradient in an ectothermic vertebrate. Oecologia 170: 641-649.

631Hobbs HH III 2012. Diversity patterns in the United States. In: Encyclopedia of caves, 632 2nd ed. White WB \& Culver DC, eds., pp 251-264. Academic Press, Amsterdam.

633Howarth FG 1980. The zoogeography of specialized cave animals: a bioclimatic model. 634 Evolution 34: 394-406.

635Howarth F G 1983. Ecology of cave arthropods. Annu. Rev. Entomol. 28: 365-389.

636Hüppop K 2012. Adaptation to low food. In: Encyclopedia of caves, 2nd ed. White WB 637 \& Culver DC, eds., pp 430-438. Academic Press, Amsterdam.

638Johnson JB, \& Omland KS 2004. Model selection in ecology and evolution. Trends 639 Ecol. Evol. 19: 101-108.

640Juberthie C 1969. Relations entre le climat, le microclimat et les Aphaenops cerberus 641 dans le grotte de Sainte-Catherine (Ariege). Annal. Spéléol. 24: 75-104.

642Juberthie C, \& Bouillon M 1983. Présence des Aphaenops (Coléoptères Trechinae) dans 643 le Milieu Souterrain Superficiel des Pyrénées. Mém. Biospéol. 10: 91-98.

644Kozel P, Pipan T, Šajna N, Polak S, \& Novak T 2017. Mitigating the conflict between 645 pitfall-trap sampling and conservation of terrestrial subterranean communities in 646 caves. Int. J. Speleol. 46: 359-368. 
647Kuštor V, \& Novak T 1980a. Individual differences in trapping activity of two 648 underground beetle species. Mém. Biospéol. 7: 77-84.

649Kuštor V, \& Novak T 1980b. Some factors influencing the efficiency of trapping two 650 underground beetle species. Zool. Anz. 205: 323-332.

651Lencioni V, Bernabo P, \& Latella L 2010. Cold resistance in two species of cave652 dwelling beetles (Coleoptera: Cholevidae). J. Therm. Biol. 35: 354-359.

653Lunghi E 2018. Ecology and life history of Meta bourneti (Araneae: Tetragnathidae) 654 from Monte Albo (Sardinia, Italy) PeerJ 6: e6049.

655Lunghi E, Manenti R, \& Ficetola GF 2014. Do cave features affect underground habitat 656 exploitation by non-troglobite species? Acta Oecol. 55: 29-35.

657Lunghi E, Manenti R, \& Ficetola GF 2017. Cave features, seasonality and subterranean 658 distribution of non-obligate cave dwellers. PeerJ 5: e3169.

659Mammola S 2018. Finding answers in the dark: caves as models in ecology fifty years 660 after Poulson and White. Ecography 41: 1-21.

661Mammola S, \& Isaia M 2014. Niche differentiation in Meta bourneti and M. menardi 662 (Araneae, Tetragnathidae) with notes on the life history. Int. J. Speleol. 43: 343-353. 663Mammola S, \& Isaia M 2016. The ecological niche of a specialized subterranean spider. 664 Invertebr. Biol. 135: 20-30.

665Mammola S, \& Isaia M 2018. Day-night and seasonal variations of a subterranean 666 invertebrate community in the twilight zone. Subterr. Biol. 27: 31-51.

667Mammola S, Piano E, Giachino PM, \& Isaia M 2015. Seasonal dynamics and micro668 climatic preference of two Alpine endemic hypogean beetles. Int. J. Speleol. 44: $669239-249$. 
670Mammola S, Giachino PM, Piano E, Jones A, Barberis M, Badino G, \& Isaia M 2016.

671 Ecology and sampling techniques of an understudied subterranean habitat: the Milieu

672 Souterrain Superficiel (MSS). Sci. Nat. 103: 88.

673Mammola S, Piano E, Giachino PM, \& Isaia M 2017. An ecological survey of the 674 invertebrate community at the epigean/hypogean interface. Subterr. Biol. 24: 27-52. 675Moldovan OT 2012. Beetles. In: Encyclopedia of caves, 2nd edn. White WB \& Culver 676 DC, eds., pp 54-62. Academic Press, Amsterdam.

677Murray BD, Webster CR, \& Bump JK 2013. Broadening the ecological context of 678 ungulate ecosystem interactions: the importance of space, seasonality, and nitrogen. 679 Ecology 94: 1317-1326.

680Novak T, Sambol J, \& Janžekovič F 2004. Faunal dynamics in the Železna jama cave. 681 Acta Carsol. 33: 249-267.

682Novak T, Kuštor V, Kranjc A, \& Sivec I 1980. Prispevek k poznavanju razporeditve 683 favne v velikih rovih. Acta Carsol. 9: 149-179.

684Novak T, Perc M, Lipovšek S, \& Janžekovič F 2012. Duality of terrestrial subterranean 685 fauna. Int. J. Speleol. 41: 181-188.

686Novak T, Šajna N, Antolinc E, Lipovšek S, Devetak D, \& Janžekovič F 2014. Cold 687 tolerance in terrestrial invertebrates inhabiting subterranean habitats. Int. J. Speleol. 688 43: 265-272.

689Novak T, Tkavc T, Kuntner M, Arnett AE, Lipovšek Delakorda S, Perc M, \& 690 Janžekovič F 2010. Niche partitioning in orbweaving spiders Meta menardi and 691 Metellina merianae (Tetragnathidae). Acta Oecol. 36: 522-529. 
692Oksanen J, Blanchet GF, Kindt R, Legendre P, Minchin PR, O'Hara RB, Simpson GL, 693 Solymos P, Stevens MHH, \& Wagner H 2016. Vegan: Community Ecology Package.

694 R package version 2.3-5. https://CRAN.R-project.org/package=vegan

695Palmer AN 2007. Cave geology. Cave books, Dayton, 454 pp.

696Peck SB 1998. A summary of diversity and distribution of the obligate cave-inhabiting 697 faunas of the United States and Canada. J. Cave Karst Stud. 60: 18-26.

698Pellegrini TG, \& Ferreira RL 2016. Are inner cave communities more stable than 699 entrance communities in Lapa Nova show cave? Subterr. Biol. 20: 15-37.

700Pipan T, \& Culver DC 2007a. Epikarst communities: biodiversity hotspots and potential 701 water tracers. Environ. Geol. 53: 265-269.

702Pipan T, \& Culver DC 2007b. Regional species richness in an obligate subterranean 703 dwelling fauna - epikarst copepods. J. Biogeogr. 34: 854-861.

704Pipan T 2005. Epikarst - A Promising Habitat. Copepod fauna, its diversity and 705 ecology: a case study from Slovenia (Europe). ZRC Publishing, Postojna, 101 pp.

706Pipan T, \& Culver DC 2012. Convergence and divergence in the subterranean realm: a 707 reassessment. Biol. J. Linn. Soc. 107: 1-14.

708Pipan T, López H, Oromí P, Polak S, \& Culver DC 2011. Temperature variation and the 709 presence of troglobionts in terrestrial shallow subterranean habitats. J. Nat. Hist. 45: $710 \quad 253-273$.

711Polak S 2012. Vertical migration of the subterranean beetles as a respond to annual tem712 perature fluctuations. In: Abstract book of the 21th International Conference on Sub713 terranean Biology. Kováč L, Uhrin M, Mock A, \& L'uptáčik P, eds., pp 90. Pavol 714 Jozef Šafárik University, Košice. 
715Poulson TL, \& Culver DC 1968. Diversity in terrestrial cave communities. Ecology 50: $716 \quad 153-158$.

717Poulson TL, \& White WB 1969. The cave environment. Science 165: 971-981.

718Poulson TL, \& Lavoie KH 2000. The trophic basis of subsurface ecosystems. In:

719 Ecosystems of the World, 30. Subterranean Ecosystems. Wilkens H, Culver DC, \& 720 Humphreys WF, eds., pp 231-249. Elsevier, Amsterdam.

721Prous X, Lopes Ferreira R, \& Jacobi CM 2015. The entrance as a complex ecotone in a 722 Neotropical cave. Int. J. Speleol. 44: 177-189.

723Prous X, Lopes Ferreira R, \& Martins RP 2004. Ecotone delimitation: Epigean724 hypogean transition in cave ecosystems. Austral. Ecol. 29: 374-382.

725R Development Core Team 2018. R: A Language and Environment for Statistical 726 Computing. R Foundation for Statistical Computing, Vienna, Austria. https://www.R727 project.org

728Raschmanová N, Šustr V, Kováč L, Parimuchová A, \& Devetter M 2018. Testing the 729 climatic variability hypothesis in edaphic and subterranean Collembola (Hexapoda). 730 J. Therm. Biol. 78: 391-400.

731Racoviţă EG 1907. Essai sur les problemes biospéologiques. Arch. Zool. Exp. Gen. 6: $732 \quad 371-488$.

733Racoviţă G 1983. Sur les relations dynamiques entre le milieu souterrain superficiel et 734 milieu cavernicole. Mém. Biospéol. 10: 85-89.

735Reboleira ASPS, Borges PAV, Gonçalves F, Serrano ARM, \& Oromí P 2011. The 736 subterranean fauna of a biodiversity hotspot region - Portugal: an overview and its 737 conservation. Int. J. Speleol. 40: 23-37.

738Romero A 2009. Cave Biology. Cambridge University Press, New York, 306 pp. 
739Schiner JR 1854. Fauna der Adelsberger-, Luegger-, and Magdalenen Grotte. In: Die

740 Grotten und Höhlen von Adelsberg, Lueg, Planina und Laas. Schmidl A, ed., pp 231-

741 272. Braumüller, Vienna.

742Šebela S 1994. The caves Jama na poti and Zguba jama. Acta Carsol. 23: 233-243.

743Šebela S, \& Turk J 2014. Natural and anthropogenic influences on the year-round 744 temperature dynamics of air and water in Postojna show cave, Slovenia. Tourism 745 Manage. 40: 233-243.

746Sendra A, \& Reboleira ASPS 2012. The world's deepest subterranean community 747 Krubera-Voronja Cave (Western Caucasus). Int. J. Speleol. 41: 221-230.

748Simon KS, Pipan T, \& Culver DC 2007. A conceptual model of the flow and 749 distribution of organic carbon in caves. J. Cave Karst Stud. 69: 279-284.

750Sket B 2008. Can we agree on an ecological classification of subterranean animals? J. 751 Nat. Hist. 42: 1549-1563.

752Sket B 2012. Diversity patterns in the Dinaric karst. In: Encyclopedia of caves, 2nd ed.

753 White WB \& Culver DC, eds., pp 228-238, Academic Press, Amsterdam.

754Soares D, \& Niemiller ML 2013. Sensory adaptations of fishes to subterranean 755 environments. BioScience 63: 274-283.

756Tobin BW, Hutchins BT, \& Schwartz BF 2013. Spatial and temporal changes in 757 invertebrate assemblage structure from the entrance to deep-cave zone of a temperate 758 marble cave. Int. J. Speleol. 42: 203-214.

759Trajano E, \& de Carvalho MR 2017. Towards a biologically meaningful classification of 760 subterranean organisms: a critical analysis of the Schiner-Racovitza system from a 761 historical perspective, difficulties of its application and implications for conservation. 762 Subterr. Biol. 22: 1-26. 
763Vandel A 1965. Biospeleology: The Biology of Cavernicolous Animals. Pergamon, 764 Oxford, $524 \mathrm{pp}$.

765Weinstein P, \& Slaney D 1995. Invertebrate faunal survey of Rope Ladder cave,

766 Northern Queensland: a comparative study of sampling methods. J. Aust. Entomol.

767 Soc. 34: 233-236.

768Wickham H 2016. ggplot2: Create Elegant Data Visualisations Using the Grammar of

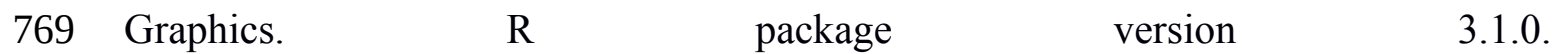

770 https://cran.r-project.org/web/packages/ggplot2/index.html

771Wynne JJ, Sommer S, Howarth FG, Dickson BG, \& Voyles KD 2018. Capturing

772 arthropod diversity in complex cave systems. Divers. Distrib., 24, 1478-1491.

773Wynne JJ, Howarth FG, Sommer S, \& Dickson BG 2019. Fifty years of cave arthropod 774 sampling: techniques and best practices. Int. J. Speleol. 48: Article 4.

775Yao Z, Dong T, Zheng G, Fu J, \& Li S 2016. High endemism at cave entrances: a case 776 study of spiders of the genus Uthina. Sci. Rep. 6: 35757.

777Yun Y, Wang H, Man B, Xiang X, Zhou J, Qiu X, Duan Y, \& Engel AS 2016. The 778 relationship between $\mathrm{pH}$ and bacterial communities in a single karst ecosystem and 779 its implication for soil acidification. Front. Microbiol. 7: 1955.

780Zagmajster M, Culver DC, \& Sket B 2008. Species richness patterns of obligate 781 subterranean beetles (Insecta: Coleoptera) in a global biodiversity hotspot - effect of 782 scale and sampling intensity. Divers. Distrib. 14: 95-105.

783Zuur AF, Hilbe JM, \& Ieno EN 2013. A Beginner's Guide to GLM and GLMM with R. 784 Highland Statistics Ltd., Newburgh, 270 pp.

785Zuur AF, Ieno EN, \& Elphick SC 2010. A protocol for data exploration to avoid 786 common statistical problems. Methods Ecol. Evol. 1: 3-14. 
787Zuur AF, Ieno EN, Walkerm NJ, Savalievm AA, \& Smith GM 2009. Mixed effect 788 models and extensions in ecology with R. Springer, Berlin, 574 pp.

789

790Fig. 1. Geographical location of the study cave (source: LIDAR DEM, Cave Register 7912018, TTN5).

792

793Fig. 2. The ground plan of Zguba jama showing sampling sections (red lines) and 794pitfall-trap sites (blue squares) with a pair of the ground and the upper trap. Modified 795from Šebela (1994) and Kozel et al. (2017).

796

797Fig. 3. (A-D) Annual mean and range of monthly measured environmental parameters; 798(E-G) parameters measured only once along the cave.

799

800Fig. 4. (A) Cumulative standardized annual species richness and the Shannon-Weaver 801index ( $\left.\mathrm{H}^{\prime}\right)$ of troglobionts per sampling section. Regression lines were obtained by 802fitting a GAM into the data (annual species richness: $\mathrm{df}=3, \mathrm{~F}=2.91, \mathrm{p}=0.053$; Shannon803Weaver index: $d f=3, F=5.73, p=0.004)$. (B) Mean \pm SD standardized annual species 804richness and Shannon-Weaver index ( $\left.\mathrm{H}^{\prime}\right)$ of troglobionts per sampling section.

805Regression lines were obtained by fitting a GAM into the data (annual species richness:

806df $=3, F=8.39, p<0.001$; Shannon-Weaver index: $d f=3, F=2.63, p=0.071$ ). For better 807visualization, confidence intervals are not shown.

808

809Fig. 5. Monthly species richness and values of the Shannon-Weaver index $\left(\mathrm{H}^{\prime}\right)$ of 810troglobionts in Zguba jama. 
812Fig. 6. Predicted values of the effects of distance from the entrance in interaction with

813the Season and (A) ground substrate temperature, and (B) substrate moisture content on 814the abundance of troglobionts obtained from the Generalized Linear Mixed Model 815(GLMM). In each panel, to generate the prediction, the unplotted variable is set at its 816 mean value.

817

818Fig. 7. Predicted values of the effects of distance from the entrance in interaction with 819the Season and (A) log-transformed passage cross-section size, and (B) ground substrate $820 \mathrm{pH}$ on the probability of the presence of troglobionts obtained from the Generalized 821Linear Mixed Model (GLMM). In each panel, to generate the prediction, the unplotted 822 variable is set at its mean value.

823

824Table 1. Model selection according to the corrected Akaike Information Criterion 825(AICc) and the Aikake weight. Models are ordered from the most to the least 826appropriate. Df, degrees of freedom; $\mathrm{w}_{\mathrm{i}}(\mathrm{AICc})$, Akaike weight.

\begin{tabular}{lccc}
\hline \hline Model structure & Df & AICc & $\begin{array}{c}\mathrm{W}_{\mathrm{i}} \\
\text { (AICc) }\end{array}$ \\
\hline Troglobionts abundance models & 13 & 1633.11 & 0.64 \\
y DisE*Season+Tgr+Tgr'+MC+offset(Area)+1|Sampling section & 14 & 1635.20 & 0.22 \\
y $\sim$ DisE*Season+Tgr+Tgr'+MC+logSize+offset(Area)+1|Sampling section & 15 & 1636.17 & 0.14 \\
y DisE*Season+Tgr+Tgr'+MC+pH+logSize+offset(Area)+1|Sampling section & 15 & & \\
Troglobionts presence-absence models & 11 & 420.41 & 0.56 \\
y DisE*Season+logSize+pH+1|Sampling section & 12 & 421.72 & 0.27 \\
y DisE*Season+logSize+pH+MC+1|Sampling section & 13 & 422.47 & 0.13 \\
y DisE*Season+logSize+pH+MC+Tgr+1|Sampling section & & &
\end{tabular}

